\title{
Proceedings
}

\section{Single Tree Stability Assessment in beech High Forest and Factors that Could Induce Windbreak ${ }^{\dagger}$}

\author{
Emiliano Gennari ${ }^{1, *}$, Francesco Latterini ${ }^{2}$, Rachele Venanzi ${ }^{1}$, Angela Lo Monaco ${ }^{1}$ and \\ Rodolfo Picchio ${ }^{1}$
}

1 Department of Agriculture and Forest Sciences (DAFNE), University of Tuscia, Via S. Camillo de Lellis, 01100, Viterbo, Italy: emiliano.gennari@unitus.it; venanzi@unitus.it; lomonaco@unitus.it; r.picchio@unitus.it

2 Consiglio per la Ricerca in Agricoltura e l'Analisi dell'Economia Agraria, Unità di Ricerca per l'Ingegneria Agraria, Rome, Italy: francesco.latterini@crea.gov.it.

* Correspondence: emiliano.gennari@unitus.it

† Presented at the 1st International Electronic Conference on Forests, 15-30 November 2020; Available online: https://sciforum.net/conference/IECF2020

Received: date; Accepted: date; Published: date

\begin{abstract}
Wind in Europe is the main disturbing factor and the greatest damaging agent of forest stands, causing three times the annual damage caused by fires each year. The amount of trees destroyed by wind annually in Europe is over 38 million cubic meters. Given the importance and extent of the phenomenon of wind crashes, this has been one of the main topics on which forestry scientists have focused over time, so much so that already in the mid-90s of the century last there were more than 200 scientific papers. However, most of these studies focused on the prediction of possible wind damage paying attention on the population level and not on a single tree; moreover, almost all of the studies were carried out on conifers. Studies concerning the single tree have been carried out above all in urban forestry, where the trees live in unfavorable contexts and very distant from what could be their optimal living conditions found in forests. The aim of this research was to search for possible correlations between the tree conformation and the crashes caused by windy events. This in order to assess the characteristics predisposing to the crash, in such a way as to provide the forest engineer with useful information in choosing the trees to be take priority in order to reduce the damage caused by windy events. In conjunction with the "Vaia windstorm", which affected much of Northern Italy, another meteoric event also occurred which caused the crash of numerous individuals inside the beech forest located on the summit of Monte Amiata, in Tuscany. In this occasion, an attempt was made to investigate the possible existence of single-tree scale indicators relating to a greater susceptibility to crash, in beech forests of the same age treated to shelterwood system, under the same phytosanitary, edaphic and topographical conditions. The research methodology applied is the same as in other studies carried out on the subject, in such a way as to allow comparison between the results obtained. Various parameters were analyzed, in particular: maximum height, crown insertion height, castle height, height corresponding to the maximum crown width, crown volume and surface. The findings showed that the main variables that had a significant influence on wind crashes were: tree height, crown surface and volume. In particular, the standing trees were taller than those crashed and with a larger crown
\end{abstract}

Keywords: Even aged high forest; Shelterwood system; Windthrow; Crown dimension

\section{Introduction}

Wind is the major damage agent in European forest [1] and various parameters influence the amount and intensity of wind damage to forest stands [2], windthrow is indeed a complex phenomenon were different factors interact with each other. Biological factors like attacks from 
pathogens, intrinsic susceptibility of the species and characteristics of the stand; and abiotic factors like wind force, topography and soil condition have a role in the windbreak phenomenon [3]. Although many factors can facilitate or not the crash, windthrow is merely a mechanical phenomenon [4], induced from interaction between resistance forces and destabilizing ones; complexity is related to the large influence of the previously mentioned factors on these forces. Such complexity induced scientific researchers to study this phenomenon in depth [5, 6], even if the major part of these studies refers to forest stands. Not much has instead been investigated about single tree features influencing windthrow. This preliminary work aimed to partially fill this knowledge gap, analyzing the single tree factors influencing windthrow in beech high stand, trying to give indications about silvicultural choices to the forest engineers.

\section{Materials and Methods}

\subsection{Site Description}

The study area is included in the beech forest present on the top of the Amiata mountain, Tuscany region. Field survey was carried out within the forest sub-compartments 18, 24, 28 and 30 of the Macchia Faggeta society forest management plan. In the four sub-compartments 27 windthrown trees were identified. The extension of the studied area was 49.4 ha, the average altitude was $1235 \mathrm{~m}$ a.s.l.; slope ranged between $10 \%$ and $70 \%$ and the age of the four sub-compartments was respectively $100,85,75$ and 95 years. In all the beech forest of Macchia Faggeta the applied silvicultural system is shelterwood. Sub-compartment 18 was interested by a first removal cut on 2014; whilst in subcompartment 30 first removal cut was carried out on 2015. On sub-compartment 24 seed cut is scheduled for 2020-2021, no previous interventions were carried out in the last 20 years. Similarly, for sub-compartment 28 , where a thinning is planned for 2020-2021 and no previous interventions have been performed in the last 20 years.

\subsection{Experimental Design}

The experimental design consisted of identifying all the windthrown trees, without considering crashed trees due to "domino effect" (crash caused from the fall of a tree against another one). The diameter at breast height of the crashed trees was measured and a standing tree of similar diameter ( $5 \mathrm{~cm}$ of tolerance) was identified near the windthrown one with which to compare. Total identified trees were 54, 27 standing trees and 27 crashed by wind, all of them has been geo-localized by GPS.

Measured parameters were:

- Maximum height of the tree;

- Crown insertion height;

- Point of crown maximum width height;

- Presence/absence of the "castle", insertion of the most major branches at the same point;

- Height of the castle;

- Crown projection on the ground detected measuring four radius called: " $\mathrm{dx}$ ", " $\mathrm{sx}$ ", " $\mathrm{c}$ " and

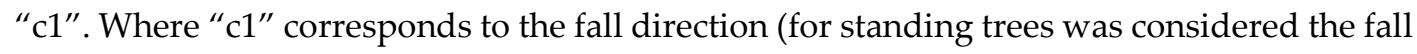
direction of the corresponding crashed tree);

- Fall direction.

Used instruments were: tree caliper, reel measure tape, VERTEX hypsometer and topography compass. 


\subsection{Data Collection and Analysis}

To measure the crown of the standing trees their projection on the ground was considered and four radii were measured from the stem, corresponding to the four apexes of interest, determined considering the fall direction of the corresponding crashed tree. Of course, it is not possible to measure the radius corresponding to the fall direction of the uprooted trees. The different heights were measured by hypsometer and the fall directions were determined using the compass. The applied crown shape model, proposed by other authors to reproduce the structure of the crown, is based on radius of the crown trend depending on the distance from the top of the tree [7]. The application of this model calculate separately the shape of the crown part exposed to sunlight and the shaded part of the crown using specific parameters for each species (Error! Reference source not found.). Slenderness coefficient was not considered. The applied experimental design, based on comparison between nearby trees with similar diameter, made useless the information about slenderness coefficient (height/diameter ratio). This because the variable "diameter" is excluded from the experimental design, and the variable "height" is considered apart as a variable influencing the windbreak.

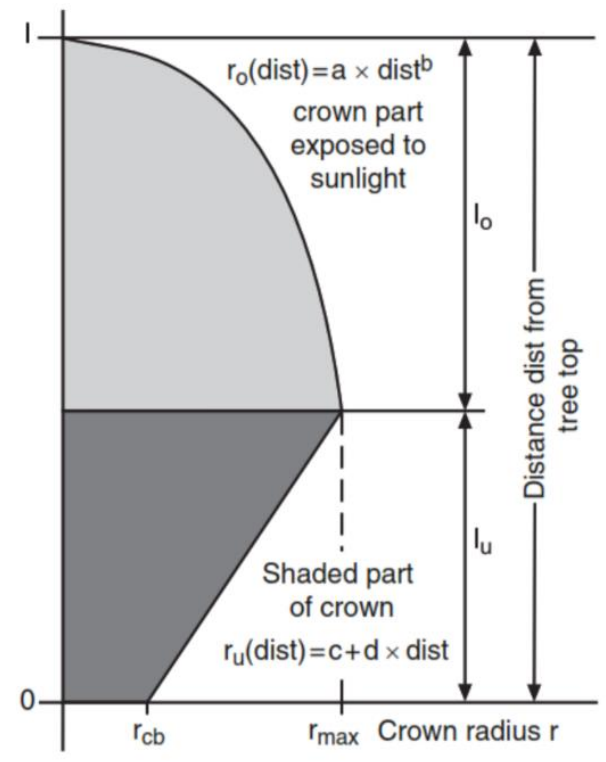

Figure 1. Beech crown shape model proposed by Pretszch, 2008.

\subsection{Statistical Analysis}

Statistical analysis was performed using Statistica 7.0 software. The conducted tests sub-were paired samples T-test, One Way ANOVA and Two-Way ANOVA, this last to investigate also the influence of the parameter "forest sub-compartment", which is an indirect measure of the influence of previous forestry interventions on windthrow,

\section{Results and Discussion}

Results of One-Way ANOVA showed statistically significant difference ( $p$-value $<0.05$ ) between standing trees and windthrown ones only concerning the parameters crown volume ( $\mathrm{p}$-value 0.005 ) and crown surface ( $\mathrm{p}$-value 0.01 ). Similar results were obtained with paired samples T-test, which showed statistically significant differences for crown volume (p-value 0.0003$)$, crown surface ( $p$-value 0.0003) and also tree height (p-value 0.0007). On the other hand, Two Way ANOVA revealed statistically significance difference for none of the investigated variables. Results of the comparison between windthrown and standing trees suggested low influence on windbreak of dendrometric parameters like height of crown insertion, height of castle and height of maximum width of the crown. Whereas, presence of statistically significance differences was found for crown surface and crown volume; tree height parameter shows statistically significance only in t-test result, but p-value 
of ANOVA test for this parameter is really near the significance threshold. Results of factorial ANOVA test indicated absence of correlation between single parameter and forest sub-compartment for all the considered variables; it means that the response to wind stress was uniform in all the forest sub-compartments, despite the differences in age of the sub-compartments and previously applied silvicultural treatments.

Table 1. Statistical analysis results (Significance threshold $\mathrm{p}$-value $<0.05 ; \mathrm{Hmax}=$ Maximum height of the tree; H1ramo = Crown insertion height; Hcastello = Height of the castle; Hlargmaxchioma = Point of crown maximum width height; S_chioma = Surface of the crown; V_chioma = Volume of the crown).

\begin{tabular}{cccc}
\hline Parameters & ANOVA & $\begin{array}{c}\text { p-value } \\
\text { Two-way ANOVA }\end{array}$ & t-test \\
\hline Hmax & 0.05069 & 0.92667 & 0.000741 \\
H1ramo & 0.76871 & 0.56910 & - \\
Hcastello & 0.27658 & 0.95223 & - \\
Hlargmaxchioma & 0.58540 & 0.71681 & - \\
S_chioma & 0.01064 & 0.54663 & 0.000282 \\
V_chioma & 0.00587 & 0.28975 & 0.000298 \\
\hline
\end{tabular}

Results showed that trees with bigger crowns, in term of surface and volume, had higher resistance to wind stress compared with trees with smaller crowns. Similar results were obtained in previous studies about windbreak [8-11]. However, there are disputes due to other studies which reported opposite conclusions. Theoretically a tree with bigger crown is exposed to greater wind stress due to larger surface exposed, added to the higher weight of the structure [12], so theoretically trees with bigger crown should be more subject to windbreak, but several studies reached different conclusion. Explanation of this phenomenon is complex and related to different causes. First, a tree with large crown has a lower center of gravity compared with a tree of the same height with smaller crown; this involves a lower overturning moment [8]. Another aspect to consider is the correlation between the extension of the crown and the root system; literature indicates for beech an extension of root system mainly inside the crown projection to the ground, to take advantage of the abundant "stemflow" of the water due to the smooth bark [13]. Furthermore, Sani [4] indicates that the overturning moment due to weight of the tree is mainly related to weight of the tree parts exceeding the root system extension; probably the presence of crown portions exceeding the root system is more frequent in plants with smaller and irregular crowns, so the overturning moment due to the weight of the plant is lower in plants with bigger and regular crowns. Moreover, trees with principal branches insert on the stem with sharp angle, condition more frequent in plants with smaller crowns, are more often subjected to vibrate with resonance frequency, this determines the amplification of the root system solicitations and promotes the crash under wind action [14]. Final consideration is about origin of beech high forests in central Italy; generally, these forests derive from conversion of aged coppices, so the bigger plants can be the old standard of the coppice, i.e. they had longer time to develop their root systems than plants derived from the coppice shoots that had to create their own root systems in shorter time.

\section{Conclusions}

From this first survey, it is possible to state a first set of suggestions. The obtained results showed that trees with larger crown have been more resistant to windthrow. According to this, it is possible to suggest during the trees selection, to release the trees with bigger and vigorous crowns; avoiding releasing of trees with most of the major branches insert at the same height due to the higher probability of vibration with resonance frequency under wind action for this trees, aspect that can compromising their stability. Further studies are needed to deep the fill the knowledge gap, also considering to perform mechanical resistance tests and adding a deeper investigation of root system extension. 
Funding: This research did not receive any specific grant from funding agencies in the public, commercial, or not-for-profit sectors.

Acknowledgments: This research was in part carried out within the framework of the MIUR (Italian Ministry for Education, University and Research) initiative "Departments of Excellence" (Law 232/2016), WP3, which financed the Department of Agriculture and Forest Science at the University of Tuscia.

Conflicts of Interest: The authors declare no conflict of interest.

\section{References}

1. Reyer, C.P.; Bathgate, S.; Blennow, K.; Borges, J.G.; Bugmann, H.; Delzon, S.; Faias, S.P.; Garcia-Gonzalo, J.; Gardiner, B.; Gonzalez-Olabarria, J.R. Are forest disturbances amplifying or canceling out climate changeinduced productivity changes in European forests? Environ Res Lett 2017. 12(3):034027

2. Gopalakrishnan, R.; Packalen, P.; Ikonen, V.P.; Räty, J.; Venäläinen, A.; Laapas, M.; Pirinen, P.; Peltola, H. The utility of fused airborne laser scanning and multispectral data for improved wind damage risk assessment over a managed forest landscape in Finland. Annals of Forest Science 2020. 77,97 https://doi.org/10.1007/s13595-020-00992-8

3. Mäenpää, H.; Peura, M.; Halme, P.; Siitonen, J.; Mönkkönen, M.; Oldén, A. Windthrow in streamside key habitats: Effects of buffer strip width and selective logging. Forest Ecology and Management 2020. volume 475 https://doi.org/10.1016/j.foreco.2020.118405

4. Sani L. Valutazione integrata dell'albero. Nicomp L.E. 2008. pp 176.

5. Taeroe, A.; de Koning, J.H.C.; Löf, M.; Tolvanen, A.; Heiðarsson, L.; Raulund-Rasmussen, K. Recovery of temperate and boreal forests after windthrow and the impacts of salvage logging. A quantitative review. Forest Ecology and Management 2019, Volume 446 Pages 304-316, ISSN 0378-1127, https://doi.org/10.1016/j.foreco.2019.03.048.

6. Ochtyra, A. Forest Disturbances in Polish Tatra Mountains for 1985-2016 in Relation to Topography, Stand Features, and Protection Zone. Forests 2020, 11, 579.

7. Pretzsch, H. Description and Analysis of Stand Structures. Forest Dynamics, Growth and Yield. 2008. 223289

8. Dunham, R.A.; Cameron, A.D. Crown, stem and wood properties of wind damaged and undamaged Sitka spruce. Forest Ecology and Management 2000. 1357381.

9. Urata, T.; Shibuya, M.; Koizumi, A.; Torita, H.; Cha, J. Y. Both stem and crown mass affect tree resistance to uprooting. J For Res 2012. 17:65-71

10. Ancelin, P.; Courbaud, B.; Fourcaud, T. Development of an individual tree-based mechanical model to predict wind damage within forest stands. Forest Ecology and Management 2004. 203 101-121.

11. Bergeron, C.; Ruel, J.C.; Elie, J.C.; Mitchell, S.J. Root anchorage and stem strength of black spruce (Picea mariana) trees in regular and irregular stands. Forestry 2009. Vol. 82, No. 1: 29-41.

12. Koizumi, A. Studies on the estimation of the mechanical properties of standing trees by non-destructive bending test. Research Bulletins of the College Experiment Forests-Hokkaido University (Japan), 1987.

13. Bernetti, G. Le piante del bosco: forme, vita e gestione. Compagnia delle Foreste 2015.

14. Sellier, D.; Fourcaud, T. Crown structure and wood properties: Influence on tree sway and response to high winds. American Journal of Botany 2009. 96(5): 885-896.

Publisher's Note: MDPI stays neutral with regard to jurisdictional claims in published maps and institutional affiliations.

(C) 2020 by the authors. Submitted for possible open access publication under the terms and conditions of the Creative Commons Attribution (CC BY) license (http://creativecommons.org/licenses/by/4.0/). 